\title{
Oldest Directly Dated Remains of Sheep
} in China

SUBJECT AREAS:

ENVIRONMENTAL

SOCIAL SCIENCES

AGROECOLOGY

Received

29 July 2014

Accepted

4 November 2014

Published

24 November 2014

Correspondence and requests for materials should be addressed to

J.D. (john.dodson@ ansto.gov.au)

\author{
John Dodson' ${ }^{2}$ Eoin Dodson ${ }^{1,5}$, Richard Banati ', Xiaogiang Li' ${ }^{2}$, Pia Atahan', Songmei Hu ${ }^{3}$, \\ Ryan J. Middleton', Xinying Zhou ${ }^{2} \&$ Sun $\mathrm{Nan}^{4}$
}

${ }^{1}$ Australian Nuclear Science and Technology Organisation, Sydney, Australia, ${ }^{2}$ Key Laboratory of Vertebrate Evolution and Human Origins of Chinese Academy of Sciences, Institute of Vertebrate Paleontology and Paleoanthropology, Chinese Academy of Sciences, Beijing, China, ${ }^{3}$ Institute of Archaeology, Xi'an, Shaanxi, China, ${ }^{4}$ Chang An University, Xi'an, China, ${ }^{5}$ Garvan Institute, Sydney, Australia.

The origins of domesticated sheep (Ovis sp.) in China remain unknown. Previous workers have speculated that sheep may have been present in China up to 7000 years ago, however many claims are based on associations with archaeological material rather than independent dates on sheep material. Here we present 7 radiocarbon dates on sheep bone from Inner Mongolia, Ningxia and Shaanxi provinces. DNA analysis on one of the bones confirms it is Ovis sp. The oldest ages are about 4700 to $4400 \mathrm{BCE}$ and are thus the oldest objectively dated Ovis material in eastern Asia. The graphitisised bone collagen had $\delta^{13} \mathrm{C}$ values indicating some millet was represented in the diet. This probably indicates sheep were in a domestic setting where millet was grown. The younger samples had $\delta^{13} \mathrm{C}$ values indicating that even more millet was in the diet, and this was likely related to changes in foddering practices

ossil sheep of Pliocene age are known for East Asia ${ }^{1}$, but domesticated sheep are thought to have arrived several millennia after they were first domesticated in the Fertile Crescent region of Western Asia e.g. Refs. 2, 3. The pathway to first domestication remains unknown but is believed to have taken place about 10,500 to 11,000 years ago and relied on the fact that sheep were docile and herded naturally ${ }^{2-4}$. They were valuable sources of meat and probably milk and milk products, and the hides were useful for leather. It is likely that several thousand years later selective breeding added fibre for wool as a new product. Dated evidence from Turkey at about $8200 \mathrm{cal}$ BC has revealed new insights into the domestication of sheep based on age and sex ratios and dung analysis ${ }^{5}$.

The earliest claimed domesticated sheep in China are based on archaeological associations with ages between 5-7000 years from Banpo village near Xi' an and Baoji, also in Shaanxi Province ${ }^{6,7}$. Other early ages are associated with sites at Shizhaocun, in Gansu ${ }^{8}$ and Hetaozhuang in Minhe, Qinghai Province ${ }^{9}$. None of these ages have been determined directly on remains of sheep, and they need revisiting to check their veracity. Presumably, sheep arrived before these early dates and it is believed sheep were first widespread across Gansu-Qinghai sometime between 5600 and $4000 \mathrm{BP}$, and on the central Plains of China by 4500-4000 BP ${ }^{10}$.

While early remains of sheep have been reported for several sites in China, the usually fragmentary and incomplete nature of those remains has tended to limit whether domesticated animals can be distinguished from wild varieties ${ }^{11}$. Ancient DNA analysis is able to resolve this issue and distinguish domestication with a high degree of certainty, as well as provide specific information about relationships between ancient and modern sheep populations. Previous work using ancient DNA analysis on sheep remains from the middle reaches of the Yellow River valley dating to ca. 2100-1800 BCE found strong genetic links to modern domestic varieties in eastern Asia $^{12,11}$. Thus far those studies have been unable to propose specific geographic origins for ancient sheep, due in part to a scarcity of genetic information from both eastern Asia and surrounding regions.

Stable carbon isotopes on fossil bone collagen are useful for palaeodiet studies. Collagen $\delta^{13} \mathrm{C}$ values indicate long-term diet averages. In northern China $\delta^{13} \mathrm{C}$ values $\leq 18 \%$ are typically regarded as mainly C3 food consumers: those with values $\delta^{13} \mathrm{C}$ between $-18 \%$ and $-12 \%$ are interpreted to have mixed $\mathrm{C} 3$ and $\mathrm{C} 4$ food consumption; and those with $\delta^{13} \mathrm{C}$ values $\geq-12 \%$ are interpreted to be mainly $\mathrm{C} 4$ consumers ${ }^{13-15}$.

In summary, these data suggest domesticated sheep came to China in the Neolithic and became widespread during the Bronze Age when societies became sedentary, but the ages of these events remain tentative in the absence of reliable dates. Here we identified sheep bone palaeontologically from sites in northern Shaanxi Province, and confirmed the identification of Ovis with DNA analysis on one sample. The AMS ages determined 


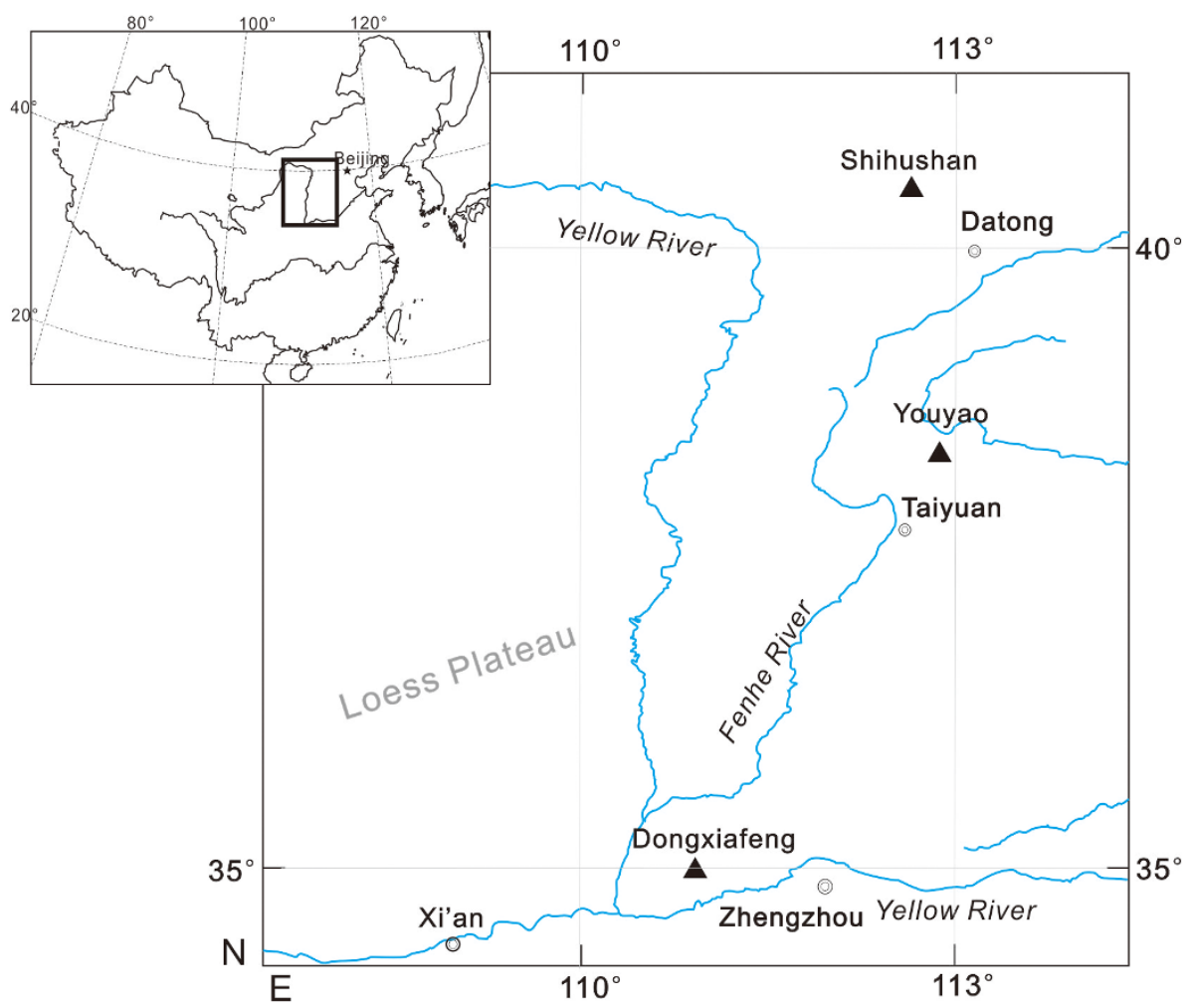

Figure $1 \mid$ Map showing the location of key sites where sheep bone was analysed for this paper. Figure 1 was designed, composed and prepared by XZ using Correl Draw software.

on the bone samples is independent of any archaeological association. In addition the stable isotopic composition was measured to provide insight into the diet of the sheep.

Study Specimens. The present study is part of a broader analysis on the impact of Prehistoric to Bronze Age cultures on environments of northern and western China ${ }^{16-22}$. In the course of this, several bone samples were collected from sediment at Shihushan, Dongxiafeng and Youyao in northern Shaanxi, and Haba Lake in Ningxia (Figure 1). The bones were removed from clayey sediment and transported to Xi'an for identification. In each case the bones were in a close archaeological context with pottery sherds, charcoal and sometimes associations of slag associated with metal working. The cultural setting is equivalent to the Yangshao. Six of the bone samples were identified as sheep (Ovis), and an additional sample from Huoshiliang (Shaanxi Province) was provided by the Shaanxi Provincial Museum. There exists a full list of taxa identified at Huoshiliang $\operatorname{site}^{23}$. About $10 \mathrm{gm}$ of each Ovis bone was transported to the laboratories of the Australian Nuclear Science and Technology Organisation (ANSTO) in Sydney for further analysis.

\section{Methods}

In the course of this, several bone samples were collected from sediment at Shihushan (probably belonging to the Yangyao Culture), and Youyao (Zhukaigou Culture: 2200-
1500 BC) in northern Shaanxi, the Dongxiafeng site (belonging to the Erlitou Culture: 1900-1500 BC) in northern Shaanxi, Haba Lake in Ningxia (Xia Dynasty: 2199-1600 BC), and Huoshiliang (Longshan to Xia Culture: 2150-1900 BC) (Figure 1). The bones were removed from clayey sediment and transported to Xi' an for identification. In each case the bones were in a close archaeological context with pottery sherds, charcoal and sometimes associations of slag associated with metal working.

Collagen was extracted from each sample and tested to determine whether preservation was sufficient and contaminants had been effectively removed to achieve reliable radiocarbon results. For this the total collagen yield (\% by weight), nitrogen and carbon percentages and the $\mathrm{C} / \mathrm{N}$ atomic ratio were measured, following established protocols ${ }^{23-26}$. Once the collagen had been extracted and determined to meet standards for reliable dating, they were processed to graphite ${ }^{27}$. The ${ }^{14} \mathrm{C}$ content was measured on the STAR Accelerator at ANSTO and AMS ages were calculated after estimating fractionation effects from the $\delta^{13} \mathrm{C}$ values determined on the samples.

DNA analysis was carried out on five of the bone samples to provide independent corroboration that the bones were indeed from sheep. DNA extraction was conducted on subsamples of the same bone fragments that were prepared for radiocarbon analysis.

In preparation, the metal utensils used during sample processing were wiped with $70 \%$ ethanol and UV irradiated, mortars and pestles were soaked in 11-14\% sodium hypochlorite solution (w/v) for $30 \mathrm{~min}$, rinsed with MilliQ water, and then dried in an oven set at $60^{\circ} \mathrm{C}$ before being used to grind bone samples. Separate mortars and pestles were used for each sample (Table 1). Approximately $500 \mathrm{mg}$ of cleaned bone was used for DNA analysis.

Bone fragments were carefully crushed, as opposed to grinding, in order to prevent localised high temperatures and further DNA damage. A negative control was used from this point onwards, in order to detect introduced contaminating DNA, from the other samples or elsewhere (Table 1).

DNA extraction was performed according to a published protocol that relies on DNA absorption to silica particles ${ }^{28}$.

Table 1 | Samples and bone fragments used for DNA analysis, including original samples sizes and DNA Nanodrop results

\begin{tabular}{|c|c|c|c|c|c|}
\hline Site & Sample ID & Bone type & Bone Fragment mass $(\mathrm{mg})$ & Bone Powder mass (mg) & DNA conc. (ng/uL) \\
\hline Shihushan & OZP087/SI3001 & Compact & 554 & 429 & 52.2 \\
\hline Shihushan & OZP086/SI2998 & Spongiose & 556 & 385.4 & 9.6 \\
\hline Shihushan & OZP085/SI2997 & Spongiose & 496 & 502.8 & 42.2 \\
\hline Dongxiafeng & OZO949/SI2921 & Compact & 491 & 500 & 51.2 \\
\hline Negative Control & - & - & - & 0 & 13.5 \\
\hline
\end{tabular}


Table 2 | Radiocarbon and stable carbon isotope analyses on sheep bone. Calibrated ages were calculated in Calib (v. 7.0.1) using the IntCal13 calibration curve 29,30

\begin{tabular}{lccccccc} 
Site & ANSTO Code & $\mathrm{C} \%$ & $\mathrm{~N} \%$ & $\mathrm{C} / \mathrm{N}$ (atomic) & $\delta^{13} \mathrm{C}(\%)$ (graphite) & Conventional ${ }^{14} \mathrm{C}$ age $(\mathrm{BP} \pm 1 \sigma)$ & $\mathrm{Calibrated}$ age $(2 \sigma) \mathrm{BCE}$ \\
\hline Shihushan & OZP087/SI3001 & 43.3 & 16.0 & 3.1 & $-19.2 \pm 0.1$ & $5740 \pm 40$ & $4695-4490$ \\
Shihushan & OZP086/SI2998 & 45.2 & 15.6 & 3.4 & $-18.9 \pm 0.1$ & $5695 \pm 35$ & $4667-4454$ \\
Shihushan & OZP085/SI2997 & 44.5 & 15.4 & 3.4 & $-19.0 \pm 0.1$ & $5665 \pm 40$ & $4601-4372$ \\
Youyao & OZO960/SI2950 & 45.3 & 15.0 & 3.4 & $-14.3 \pm 0.1$ & $3750 \pm 45$ & $2292-2029$ \\
Dongxiafeng & OZO949/SI2921 & 45.0 & 15.4 & 3.4 & $-17.0 \pm 0.1$ & $3360 \pm 45$ & $1713-1570$ \\
Huoshiliang & OZO951/SI2891 & 45.0 & 15.6 & 3.4 & $-15.5 \pm 0.1$ & $3750 \pm 50$ & $2334-1983$ \\
Haba Lake & OZN204/SI1592 & 44.0 & 15.0 & 3.3 & $-17.0 \pm 0.1$ & $4090 \pm 30$ & $2859-2499$
\end{tabular}

\section{Results}

Seven radiocarbon ages on sheep collagen have been obtained and have a calibrated age range (with errors) from 4700 to $1570 \mathrm{BCE}$ (Table 2). Three radiocarbon ages of about $5700 \mathrm{BP}$ (4700 to 4400 BCE) are statistically identical, and they overlap the Neolithic (Yangshao) and Bronze Age boundary. These are the oldest directly dated sheep material from eastern Asia. The $\delta^{13} \mathrm{C}$ values of the older bones indicate the sheep had a diet based largely on $\mathrm{C} 3$ plants but the $\delta^{13} \mathrm{C}$ values are close to the boundary of diets based on $\mathrm{C} 3$ and $\mathrm{C} 4$ plants (Table 1).

Out of the five bone samples only the Youyao bone produced a specific amplification product. The 78 nucleotide sequence shares $100 \%$ identity with Ovis aries mitochondrial DNA (mtDNA) and in addition the sequence also shares $100 \%$ identity with mtDNA from $O$. orientalis anatolica, O. vignei and O. ammon which are Turkish and Central Asian species, that are possible ancestors of domestic sheep.

\section{Discussion}

The identification of the bones on physical characteristics and DNA fragment confirms the bone samples are from the genus Ovis (sheep). The radiocarbon age of $5700 \mathrm{BP}$ (4700 to $4400 \mathrm{BCE}$ ) for the three bones from Shihushan is the oldest independent age for sheep in eastern Asia. Since the bones were found in association with other domestic species and in an archaeological setting of the Yangshao Culture it is a reasonable conclusion that the sheep were domesticated. This is further supported by the stable isotope analyses on graphite prepared from bone collagen that had values ranging from -19.2 to $-14.3 \%$. In all likelihood some millet was consumed by the sheep (the Asian millets are the C4 plants Panicum miliaceum and Setaria italica), but the bulk of the diet was comprised of C3 plants. The younger samples from Youyao and Huoshiliang had less negative $\delta^{13} \mathrm{C}$ values, suggesting that millet was a larger proportion of the diet in these cases, and this possibly related to changes in foddering practices occurring over time. This is quite unlike the diet of pigs, rats and dogs from similar settings which had even less negative values and suggest they had diets strongly influenced by millet, including meat from possibly domesticated animals that were fed on millet ${ }^{19}$. Deer, cattle and sheep $\delta^{13} \mathrm{C}$ values indicate that in general wild animals and herds grazed beyond the agricultural zone but sheep had some C4 plants, possibly millet, in their diet ${ }^{19}$. The younger Ovis samples suggest that the amount of millet in the diet increased and possibly indicates a change in foddering practice. It is unfortunate that a longer DNA sequence could not be recovered from the collagen, particularly from the older samples, as this could shed light on the early ancestors of the domesticated sheep.

1. Mead, J. \& Taylor, L. New species of Sinocarpa (Bovidae, Caprinae) from the Lower Pliocene Panaca Formation, Nevada, USA. Palaeontologia Electronica Vol. 8, article 8.1.11, 20 pp (2005).

2. Peters, J. et al. The Upper Euphrates-Tigris Basin: cradle of agro-pastoralism? [Vigne, J. et al. (eds.)] [96-124] The first steps of animal domestication. New Archaeological Approaches. (Oxbow Books, Oxford, UK, 2005).
3. Zeder, M. Domestication and early agriculture in the Mediterranean Basin: origins, diffusion, and impact. Proc. Nat. Acad. Sci. 105, 11, 597-11, 604 (2008).

4. Clutton-Brock, J. \& Uerpmann, H-P. Sheep of early Jericho. J. Arch. Sci. 1, 261-274 (1974)

5. Stiner, M. et al. A forager-herder trade-off, from broad-spectrum hunting to sheep management at Așıklı Höyük, Turkey. Proc. Nat. Acad. Sci. 111, 8404-8409 (2014).

6. Li, Y. \& Han, D. Animal remains excavated from Beishouling Neolithic site at Baoji. Paleovertebrata et Paleoanthropologia 1, 173-185 (1959).

7. Zhou, B. Animal remains excavated from Beishouling Neolithic site at Baoji. [The Institute of Archaeology, Chinese Academy of Social Science (ed.)] Excavation of the Beishouling Site at Baoji. [Cultural Relics Publishing House, Beijing (in Chinese), 1983].

8. Zhou, B. Animal remains excavated from Shizhaocun and Xishanping site. [ The Institute of Archaeology, Chinese Academy of Social Science (ed.)] Shizhaocun and Xishanping. [The Chinese Encyclopaedia. China Publishing House, Beijing (in Chinese), 1999].

9. Sang, G. Tomb No. 1 of the Majiayao-relic type, Hetaozhuang of Minhe County, Qinghai. Cultural Relics 9, 29-32 (in Chinese) (1979).

10. Yuan, J. et al. Animal archaeological study on Zhongyuan region from 2500 to 1500 BC- based on the example of Taosi, Wengchenggang, Xinci and Erlitou sites. [ The Institute of Archaeology, Chinese Academy of Social Science (ed.)] [Science Press, Beijing (in Chinese), 2007].

11. Cai, D. et al. Early history of Chinese domestic sheep indicated by ancient DNA analysis of Bronze Age individuals. J. Arch. Sci. 38, 896-902 (2011).

12. Cai, D. et al. DNA analysis of archaeological sheep remains from China. J. Arch. Sci. 34, 1347-1355 (2007).

13. Barton, L. et al. Agricultural origins and the isotopic identity of domestication in northern China. Proc. Nat. Acad. Sci. 106, 5523-5528 (2009).

14. Ma, M. et al. Stable isotope analysis of human and faunal remains in the western Loess Plateau, approximately $2000 \mathrm{cal}$. BC. Archaeometry doi:10.1111/ arcm.12071, p 237-255 (2013).

15. Pechenkina, E. et al. Reconstructing northern Chinese Neolithic subsistence practices by isotopic analysis. J. Arch. Sci. 32, 1176-1189 (2005).

16. Li, X. et al. Early cultivated wheat and broadening of agriculture in Neolithic China. The Holocene, 17, 555-560 (2007).

17. Li, X. et al. The impact of early smelting on the environment of Huoshiliang in Hexi Corridor, NW China, as recorded by fossil charcoal and chemical elements. Palaeogeog., Palaeoclim. Palaeoecol. 305, 329-336 (2011).

18. Dodson, J. et al. Early bronze in two Holocene archaeological sites in Gansu, NW China. Quat. Res. 72, 309-314 (2009).

19. Atahan, P. et al. Subsistence and the isotopic signature of herding in the Bronze Age Hexi Corridor, NW Gansu, China. J. Arch. Sci. 38, 1747-1753 (2011).

20. Dodson, J. et al. Origin and spread of wheat in China. Quat. Sci. Rev. 72, 108-111 (2013).

21. Sun, N. et al. Plant diversity of the Tianshui Basin in the western Loess Plateau during the mid-Holocene - Charcoal records from archaeological sites. Quat. Internat. 308-309, 27-35 (2013).

22. Dodson, J. et al. Use of coal in the Bronze Age in China. The Holocene 24, 525-530 (2014).

23. $\mathrm{Hu}, \mathrm{S}$. et al. A study on the faunal remains from the Huoshiliang site in Yulin, Shaanxi. Acta Anthropol. Sinica 27, 232-248 (2008).

24. Higham, T. et al. AMS Radiocarbon Dating of Ancient Bone Using Ultrafiltration. Radiocarbon 48, 179-195 (2006).

25. Bronk Ramsey, C. et al. Improvements to the Pretreatment of Bone at Oxford. Radiocarbon 46, 155-163 (2004).

26. Brown, T. et al. Improved Collagen Extraction by Modified Longin Method. Radiocarbon 30, 171-177 (1988).

27. Hua, Q. et al. Progress in Radiocarbon Target Preparation at the ANTARES AMS Centre. Radiocarbon 43, 275-282 (2001).

28. Rohland, N. DNA Extraction of Ancient Animal Hard Tissue Samples via Adsorption to Silica Particles. Meth. Molecul. Biol. 840, 21-28 (2012).

29. Reimer, P. et al. INTCAL09 and Marine 09 radiocarbon age calibration curves, 0 50,000 years cal BP. Radiocarbon 55, 1869-1887 (2013). 
30. Stuiver, M. \& Reimer, P. Extended 14C database and revised CALIB radiocarbon calibration program. Radiocarbon 35, 215-230 (1993).

\section{Acknowledgments}

We are grateful for support from the Australian Nuclear Science and Technology Organisation and the support of National Natural Science Foundation of China (Grant No. 41172161, 40572108)

\section{Author contribution}

J.D., X.L., P.A., X.Z. and S.N. participated in the fieldwork, and collected the samples. S.H. identified the bones and provided the museum specimen for analysis, E.D., R.B. and R.M. carried out the DNA analysis and interpretation, J.D. and P.A. assisted in the radiocarbon analysis and all contributed to the writing of the manuscript.

\section{Additional information}

Competing financial interests: The authors declare no competing financial interests.

How to cite this article: Dodson, J. et al. Oldest Directly Dated Remains of Sheep in China. Sci. Rep. 4, 7170; DOI:10.1038/srep07170 (2014).

(c) (i) $(-)$ This work is licensed under a Creative Commons Attribution-NonCommercialNoDerivs 4.0 International License. The images or other third party material in this article are included in the article's Creative Commons license, unless indicated otherwise in the credit line; if the material is not included under the Creative Commons license, users will need to obtain permission from the license holder in order to reproduce the material. To view a copy of this license, visit http:// creativecommons.org/licenses/by-nc-nd/4.0/ 